\title{
Applicability of the real-time PCR assay in the amplification of cyanobacterial DNA from preserved samples
}

\author{
Catarina Churro ${ }^{1,2, *}$, Elisabete Valério ${ }^{1}$, Paulo Pereira $^{1}$ and Vitor Vasconcelos ${ }^{2,3}$ \\ ${ }^{1}$ Laboratório de Biologia e Ecotoxicologia, Departamento de Saúde Ambiental, Instituto Nacional de Saúde Dr. \\ Ricardo Jorge, Avenida Padre Cruz, 1649-016 Lisboa, Portugal. \\ ${ }^{2}$ Departamento de Biologia, Faculdade de Ciências, Universidade do Porto, Rua do Campo Alegre, 4069-007 \\ Porto, Portugal. \\ ${ }^{3}$ Centro Interdisciplinar de Investigação Marinha e Ambiental, CIIMAR/CIMAR, Universidade do Porto, Rua \\ dos Bragas 280, 4050-123 Porto, Portugal.
}

* Corresponding author: catarina.churro@insa.min-saude.pt

Received: 21/01/2014 Accepted: 28/09/2014

\begin{abstract}
Applicability of the real-time PCR assay in the amplification of cyanobacterial DNA from preserved samples

The study and monitoring of cyanobacterial blooms often involves the use of preserved samples to avoid cellular degradation. However, preserved samples may not be suitable for molecular biology studies because preservation methods can interfere with DNA quality/quantity. Real-time quantitative PCR analysis (qPCR) has been widely applied in molecular analysis and is considered a promising method for monitoring purposes. This study intended to evaluate the applicability of the real-time qPCR technique in samples that were subjected to different methods of preservation: (1) 15\% Lugol's iodine solution (2) 4\% formaldehyde and (3) 25\% glutaraldehyde. The ability to amplify and quantify DNA extracted from Planktothrix agardhii was assessed using the $r p o \mathrm{C} 1$ gene as the target fragment in both raw water samples and in vitro cultures.

No reliable DNA amplification was obtained from glutaraldehyde-preserved samples. Successful amplification was obtained from Lugol's and formaldehyde-preserved samples. In this case, however, the quantification that was achieved by real-time PCR cannot be used to infer cell numbers, because the Ct values that were obtained from the Lugol's and formaldehydepreserved samples were significantly higher than the $\mathrm{Ct}$ values that were obtained from the unpreserved samples. Therefore real-time PCR can be used for the detection and identification of cyanobacteria in preserved samples but no reliable cell quantification can be performed using this method.
\end{abstract}

Key words: Cyanobacteria, formaldehyde, glutaraldehyde, lugol's iodine, real-time qPCR, Planktothrix.

\section{RESUMEN}

Aplicabilidad del qPCR en tiempo real en la amplificación de ADN de cianobacterias procedente de muestras fijadas

El estudio y la vigilancia de las floraciones de cianobacterias implican a menudo el uso de muestras conservadas, con el fin de evitar la degradación celular. Sin embargo, las muestras conservadas pueden no ser adecuadas para los estudios de biología molecular, ya que los métodos de conservación pueden interferir con la calidad/cantidad del ADN. Este estudio pretende evaluar la aplicabilidad de la técnica de qPCR en tiempo real en muestras sometidas a diferentes métodos de conservación: (1) $15 \%$ de solución yodoyodurada de Lugol (2) $4 \%$ de formaldehído y (3) $25 \%$ de glutaraldehído. La capacidad para amplificar y cuantificar el ADN extraído de Planktothrix agardhii se evaluó utilizando un fragmento del gen rpoCl en ambas muestras de agua bruta y en cultivos in vitro.

No se obtuvo amplificación fiable de ADN a partir de muestras conservadas en glutaraldehído. El fragmento de gen rpoC1 se amplificó con éxito en ADN extraído de muestras conservadas en solución yodoyodurada de Lugol y formaldehído. En este caso, sin embargo, la cuantificación lograda por PCR en tiempo real no puede utilizarse para inferir el número de células; ya que los valores de Ct obtenidos a partir de muestras conservadas en lugol y formaldehído fueron significativamente más elevados que los valores de Ct obtenidos a partir de las muestras sin conservantes. Por lo tanto, PCR en tiempo real se puede utilizar para la detección y la identificación de cianobacterias en muestras conservadas, pero sin cuantificación fiable de células. 
Palabras clave: Cianobacterias, formaldehído, glutaraldehído, solución yodurada de lugol, qPCR en tiempo real, Planktothrix.

\section{INTRODUCTION}

Preserved phytoplankton samples represent a resource of cyanobacterial DNA for molecular studies, regardless of whether they have been preserved for a short or long time. The evaluation of the usefulness of preserved samples in the real-time quantitative PCR (qPCR) method is relevant for the implementation of this technique in water quality monitoring. Several authors have reported the amplification of nucleic acids from preserved phytoplanktonic samples in dinoflagellates (Godhe et al., 2002; Galluzzi et al., 2004), microalgae and other protists (Auinger et al., 2008, Shuang et al., 2013). These studies intend to bypass time-consuming microscopic examinations (Galluzzi et al., 2004), establish phylogenetic diversity (Godhe et al., 2002; Galluzzi et al., 2004; Qiu et al., 2011; Shuang et al., 2013), establish a direct link between morphological and molecular screening approaches (Auinger et al., 2008) or simply permit the identification and quantification of species that may be overlooked by microscopic identification (Godhe et al., 2002; Lang \& Kaczmarska, 2011). In cyanobacteria, reports addressing the availability and PCR amplification of cyanobacterial DNA that was recovered from preserved

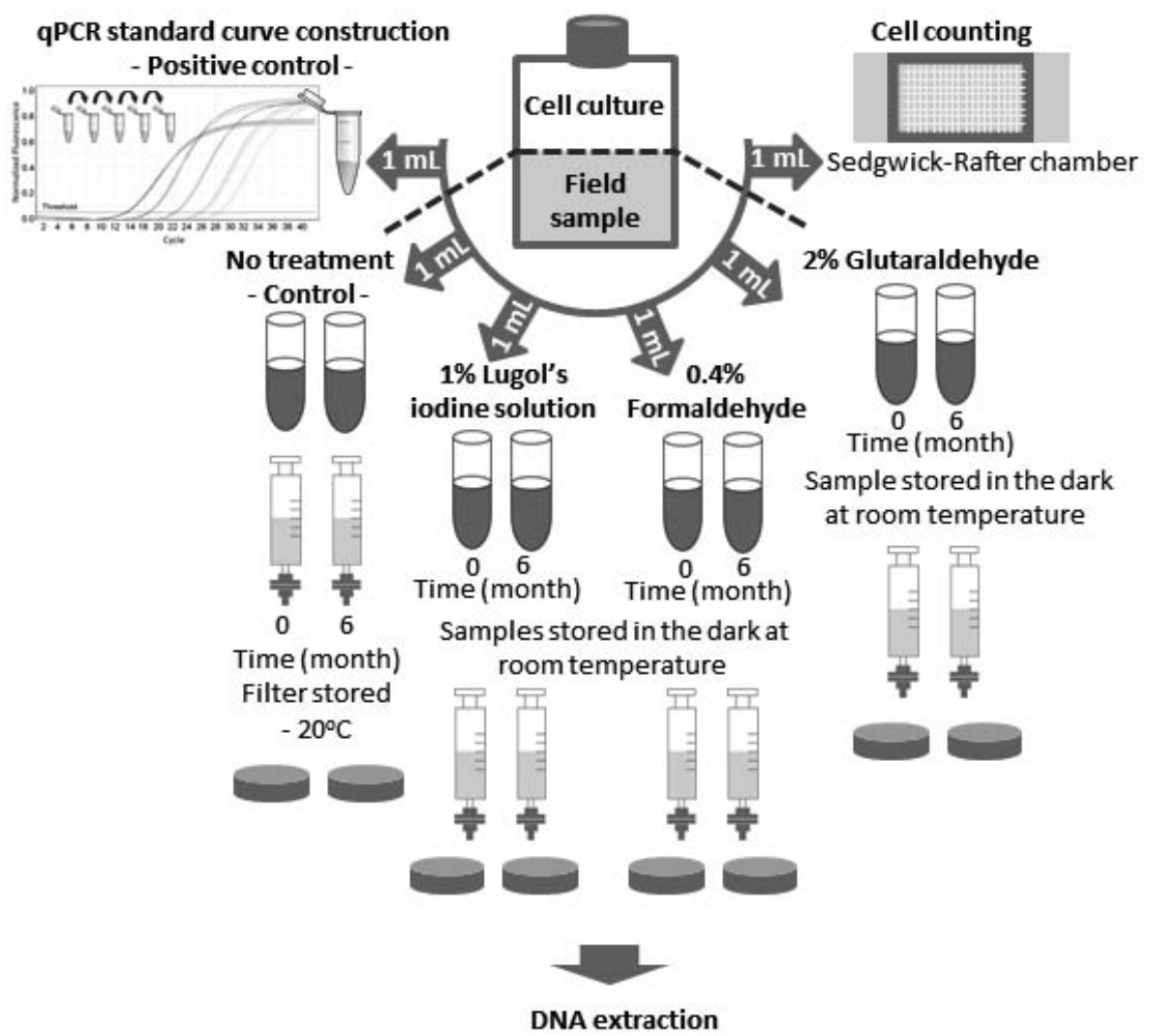

Figure 1. Diagram describing the method that was used for culture and field sample preservation. Esquema del método de preservación utilizado para muestras de cepas y muestras de campo. 
samples are not available. This study addresses two questions: Can the real-time PCR reaction amplify DNA that is extracted from preserved cyanobacteria samples, and if so, can the realtime qPCR results of preserved samples be used to establish a valid correlation with cyanobacteria densities in environmental samples? Fixatives that are often used for the long-term storage of phytoplankton material include Lugol's iodine (Hötzel \& Croome, 1999; Utkilen et al., 1999), formaldehyde and glutaraldehyde solutions (Menden-Deuer et al., 2001; Bertozzini et al., 2005; Karlson et al., 2010). In this study, we evaluated the applicability of the real-time PCR technique in the amplification of a target fragment in DNA that was extracted from samples that were preserved with Lugol's iodine solution, formaldehyde and glutaraldehyde.

\section{MATERIAL AND METHODS}

\section{Culture and field sample preservation treatments}

\section{Cyanobacteria species and genetic marker}

To evaluate the amplification by the real-time PCR of cyanobacterial DNA that was extracted from preserved samples, the culture experiments were performed with nonaxenic monoclonal cultures of Planktothrix agardhii. The gene that was used for the PCR amplification was the rpoC1 that encodes the characteristic cyanobacterial $\delta$ subunit of the DNA-dependent RNA polymerase using the primers rpoC1_Plank_F271 (5'-TGT TAAATCCAGGTAACTATGACGGCCTA- ${ }^{\prime}$ ) and rpoC1_P_agardhii_R472 (5'-GCGTTTTTGTCC CTTAGCAACGG-3'), targeting a fragment of 202 bp (Churro et al., 2012).

\section{Cyanobacteria cultures and field samples}

The P. agardhii strains (lmecya 153A, 153B and $155)$ that were used in the experiments were maintained in the Estela Sousa e Silva Algal Culture Collection in the Laboratory of Biology and Ecotoxicology (LBE) at the National Health Ins- titute Dr. Ricardo Jorge, Portugal. Further information about the cultures can be found in Paulino et al. (2009). The field sample that was used in the experiments was obtained from an ongoing monitoring program at the LBE that receives samples periodically from a water reservoir with recurrent blooms of $P$. agardhii.

\section{Sampling}

One-millilitre culture samples and $25-\mathrm{mL}$ field samples were preserved separately with three working solutions that were made according with Edler \& Elbrächter (2010): 15\% acidic Lugol's iodine solution at $\mathrm{pH} 3$ (final concentration of $1 \%$ ); $4 \%$ neutral buffered formaldehyde at pH 7 (final concentration of 0.4\%); and 25\% glutaraldehyde at $\mathrm{pH} 7$ (final concentration of $2 \%$ ). The samples were kept in the dark for $24 \mathrm{~h}$ or 6 months at room temperature until DNA extraction (Fig. 1).

\section{Control samples}

Because preserved samples and field samples must be filtered to remove excess fixative solution or field water, a sample with no preservation treatment was used as a control and filtered through a syringe with a Swinnex $₫($ Millipore) holding a paper filter (Fig. 1). To test whether the filtering step influenced DNA attainment, the control sample was compared to the wholesample positive control, which was also used for standard curve construction (Fig. 1). Both of the non-treatment samples were stored at $-20^{\circ} \mathrm{C}$ for $24 \mathrm{~h}$ or 6 months until DNA extraction. No differences were obtained between the filtered (control) and the non-filtered (positive control) samples, which were also stable after 6 months (Fig. 2). Based on these tests, the $\mathrm{Ct}$ values that were obtained from the amplification of preserved samples were only compared to the $\mathrm{Ct}$ values of the control sample.

\section{gDNA extraction}

The preserved samples were filtered through a syringe with a Swinnex $\AA$ (Millipore) holding a pa- 
per filter (Fig. 1). The filter was then placed into a 2-mL Eppendorf tube, and DNA was extracted by phenol-chloroform extraction as described in Churro et al. (2012). The DNA of the control and positive control was also extracted by the same method to assure that all of the samples had the same treatment. The gDNA was eluted in $50 \mu \mathrm{L}$ of DNase-free water and quantified with a spectrophotometer. After quantification, the $50-\mu \mathrm{L}$ DNA extracts were diluted in $950 \mu \mathrm{L}$ of DNase-free water.

\section{gDNA quantitation, quality and integrity}

After extraction, the DNA concentration and purity were measured using a NanoDrop $\mathbb{R}$ ND1000 spectrophotometer (Thermo Fisher Scientific, Wilmington, DE). The DNA was quantified $(\mathrm{ng} / \mu \mathrm{L})$ using the spectrophotometric measurement of UV absorption at a 260-nm wavelength. The DNA purity was determined by the ratios OD260/OD280 and OD260/OD230. Values of the OD260/280 ratio between 1.8 and 2.0 and of the OD260/230 ratio between 2.0 and 2.2 were considered to indicate pure DNA (Vinod, 2004). The integrity of the total gDNA that was extracted from the $20-\mathrm{mL}$ preserved samples of $P$. agardhii (lmecya 153B) culture was checked in a $0.6 \% \mathrm{w} / \mathrm{v}$ agarose gel. The electrophoresis was performed at $85 \mathrm{~V}$ in $0.5 \times$ Tris-borate EDTA (TBE) buffer for $45 \mathrm{~min}$. The gDNA migration was visualized by exposure to ultraviolet light after GelRed ${ }^{\mathrm{TM}}$ staining.

\section{Real-time qPCR analysis of preserved samples}

\section{Standard curve construction}

The standard curve construction for real-time qPCR was based on the cell numbers from $P$. agardhii cultures. Because the rpo $\mathrm{C} 1$ gene exists as a single copy in the cyanobacteria genome, one cell will correspond to one copy of this gene. The culture cell density was estimated by Light Microscopy (LM) using a Sedgwick-Rafter chamber. As previously mentioned, at the time of the culture sampling for preservation, an identical
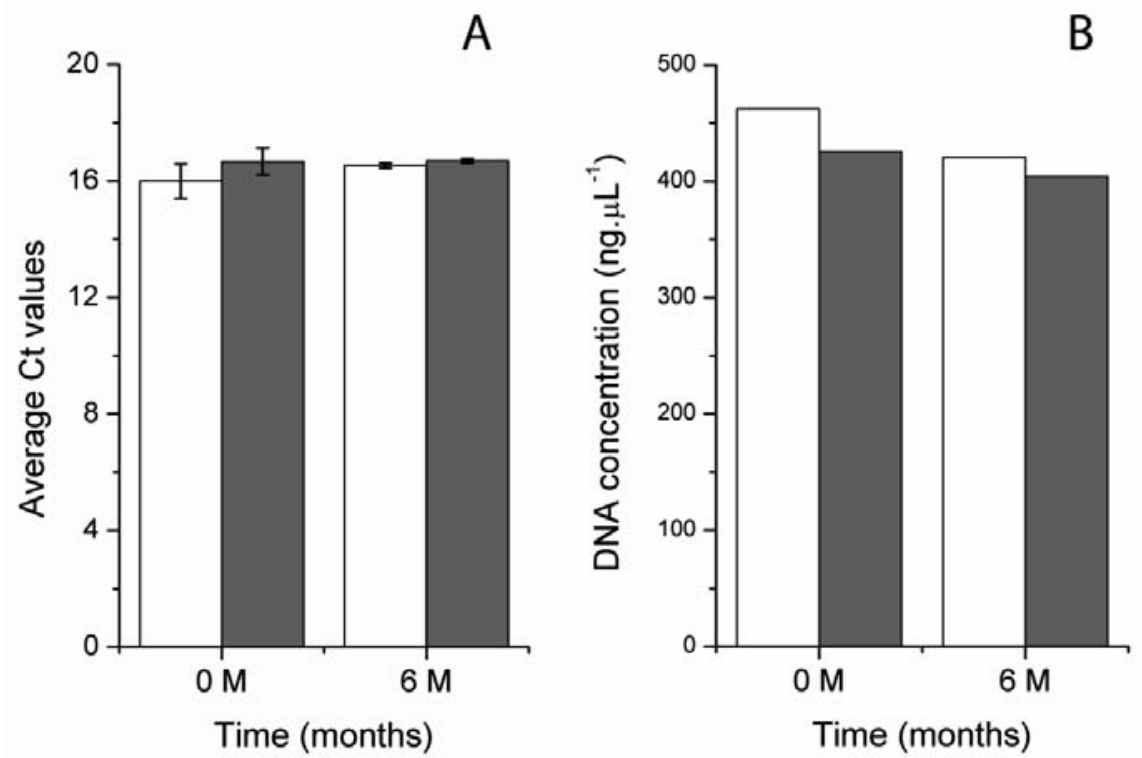

Figure 2. Stability of the control samples. (A) Ct values and (B) DNA concentrations at the time of preservation (0 M) and over a 6-month period $(6 \mathrm{M})$. White bar-positive control, grey bar-control (filter with no treatment). The lines represent the standard deviation. No significant differences, Student's $t$ test, $\mathrm{df}=4, p>0.05$. Estabilidad de las muestras de control. (A) valores de Ct y (B) concentraciones de DNA en el momento de la conservación (0 M) y durante un período de 6 meses (6 M). Barra blancacontrol positivo, barra gris-control (filtro sin ningún tratamiento). Las líneas representan la desviación estándar. No hay diferencias significativas, prueba $\mathrm{t}$ de Student, $d f=4, \mathrm{p}>0.05$. 
1-mL sample was taken for the standard curves (Fig. 1). This sample was diluted in 5 serial 10fold dilutions to construct the calibration curves. The standard curve equations, reaction amplification efficiencies and cell culture densities are presented in Table 1.

\section{qPCR conditions}

The real-time qPCR assays were performed on a Rotor Gene Q (Qiagen) using SYBR Green I Dye. The following reagents were added in a $12.5-\mu \mathrm{L}$ reaction mixture: $6.25 \mu \mathrm{L}$ of Sensi$\mathrm{Mix}^{\mathrm{TM}}$ SYBR NO-ROX kit real-time qPCR MasterMix (Bioline), $0.1 \mu \mathrm{M}$ forward and reverse primers and $4 \mu \mathrm{L}$ of template DNA. The thermal cycling conditions consisted of an initial preheating step of $3 \mathrm{~min}$ at $94{ }^{\circ} \mathrm{C}$ followed by 40 cycles of $20 \mathrm{~s}$ at $94{ }^{\circ} \mathrm{C}, 20 \mathrm{~s}$ at $58^{\circ} \mathrm{C}$ and $20 \mathrm{~s}$ at $72^{\circ} \mathrm{C}$. The specificity of the amplified PCR product was verified by melting curve analysis at the end of the 40 cycles by gradually increasing the temperature from 60 to $95^{\circ} \mathrm{C}$ by $1{ }^{\circ} \mathrm{C}$ every $5 \mathrm{~s}$. The threshold line was set at 0.05 of the signal fluorescence for all of the PCR tests using the RotorGene Q series software.

\section{Statistical analysis and replicates}

The differences in the amplification were assessed by comparing the cycle threshold values $(\mathrm{Ct})$. The non-treatment control group -control and positive control- was used to determine the expected $\mathrm{Ct}$ values. A statistical analysis was performed using Student's $t$-test, and a $p$ value $<0.05$ was considered significantly different. All of the samples were run in triplicate in the real-time PCR reaction. The tests were repeated in 3 independent experiments.

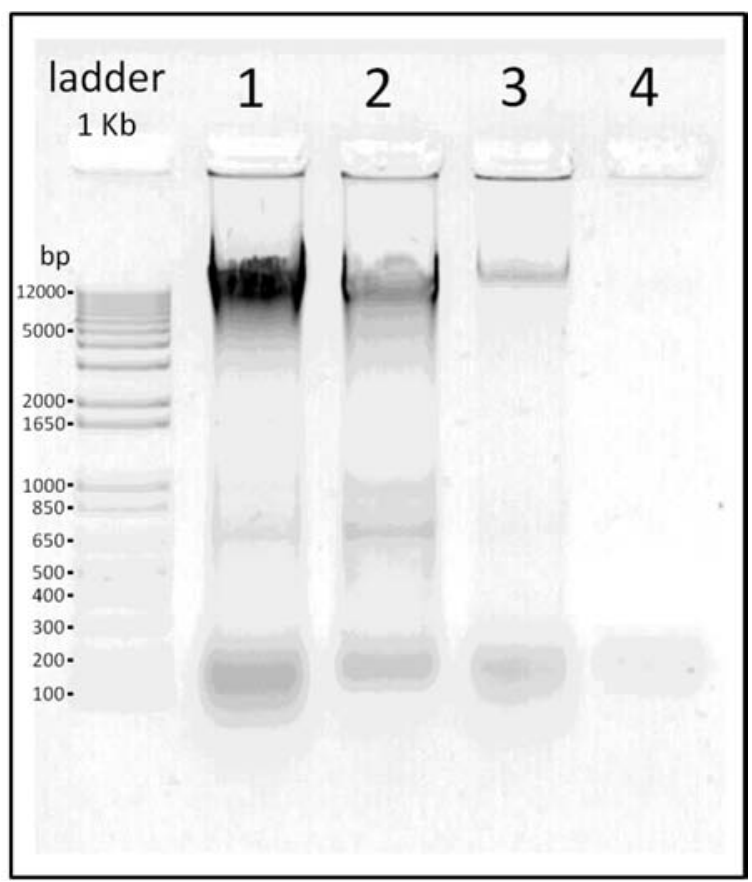

Figure 3. Migration of gDNA that was extracted from the preserved and control samples in $0.6 \%(\mathrm{w} / \mathrm{v})$ agarose gel electrophoresis at $85 \mathrm{~V}$ in TBE buffer for $45 \mathrm{~min}$. (1) Unpreserved sample-control; (2) $15 \%$ Lugol's-iodine-solutionpreserved samples; (3) 4\% formaldehyde-preserved samples; and (4) $25 \%$ glutaraldehyde-preserved samples. Ladder: GeneRuler ${ }^{\mathrm{TM}}$ DNA Ladder Mix (Fermentas). Migración de DNA genómico extraído de muestras conservadas y muestra control en gel de agarosa al 0.6\% ( $w / v)$ a $85 \mathrm{~V}$ en tampón TBE durante 45 min. (1) Muestra sin conservantes-control; (2) solución yodoyodurada de Lugol al 15\%; (3) formaldehído al $4 \%$; (4) glutaraldehído al $25 \%$.

\section{PCR inhibition and sensitivity}

To test whether the DNA extracts from the preserved samples inhibited the PCR, the reaction efficiency was accessed in the 5 serial 10-fold dilutions of the preserved samples. If the sample contained any PCR inhibitor, the amplification of the 10-fold dilutions would not be linear be-

Table 1. Real-time PCR standard curve equations and reaction amplification efficiencies. Curva de calibrado y eficiencia de la reacción de la amplificación en la PCR en tiempo real.

\begin{tabular}{lcccccc}
\hline & $\begin{array}{c}\text { Strain } \\
\text { (lmecya) }\end{array}$ & $\begin{array}{c}\text { Culture cell densities } \\
\text { (Cells/mL) }\end{array}$ & $\begin{array}{c}\text { Standard curve } \\
\text { equation }\end{array}$ & $\begin{array}{c}\text { Amplification } \\
\text { efficiency }\end{array}$ & $\begin{array}{c}\text { R } \\
\mathrm{R}^{2}\end{array}$ & $\begin{array}{c}\text { Cell range } \\
\text { (cells/reaction) }\end{array}$ \\
\hline Experiment I & 155 & $152.07 \cdot 10^{5}$ & $y=-3.59 \log (x)+31.42$ & 0.90 & 0.997 & 60828 to 6 \\
Experiment II & 155 & $231.74 \cdot 10^{5}$ & $y=-3.43 \log (x)+31.19$ & 0.96 & 0.998 & 92698 to 9 \\
Experiment III & $153 \mathrm{~A}$ & $474.30 \cdot 10^{5}$ & $y=-3.59 \log (x)+34.09$ & 0.90 & 0.995 & 189692 to 19 \\
\hline
\end{tabular}


cause the inhibitor would be diluted and the target fragment might be better amplified in lowconcentration samples (Wilson, 1997). To compare the sensitivity of real-time PCR with that of conventional PCR in the amplification of the target fragment, the preserved samples were also diluted in 5 serial ten-fold dilutions and amplified in both conventional PCR and real-time PCR.

\section{Conventional PCR conditions}

End-point PCR amplification of the rpoC1 gene fragment was performed in a $25-\mu \mathrm{L}$ reaction mixture containing $1 \times \mathrm{PCR}$ buffer (Invitrogen $^{\mathrm{TM}}$ ), $0.05 \mathrm{mM}$ dNTPs (Invitrogen ${ }^{\mathrm{TM}}$ ), $0.2 \mu \mathrm{M}$ each primer (rpoC1_Plank_F271 and rpoC1_P _agardhii_R472), 2 mM MgCl 2 (Invitrogen ${ }^{\mathrm{TM}}$ ), $8 \mu \mathrm{L}$ of DNA extract and $1 \mathrm{U}$ of Taq DNA polymerase (Invitrogen ${ }^{\mathrm{TM}}$ ). The amplification was performed in a TGradient Thermocycler (Biometra) consisting of an initial denaturation step at $94{ }^{\circ} \mathrm{C}$ for $3 \mathrm{~min}$, followed by 40 cycles of $20 \mathrm{~s}$ at $94^{\circ} \mathrm{C}, 20 \mathrm{~s}$ at $58^{\circ} \mathrm{C}$ and $20 \mathrm{~s}$ at $72^{\circ} \mathrm{C}$ and a final extension step of $5 \mathrm{~min}$ at $72{ }^{\circ} \mathrm{C}$. The amplified rpoC1 fragments were visualized by exposure to ultraviolet light in a GelRed ${ }^{\mathrm{TM}}$ -stained $1 \% \mathrm{w} / \mathrm{v}$ agarose gel after electrophoresis at $85 \mathrm{~V}$ in $0.5 \times$ Tris-borate EDTA (TBE) buffer for $45 \mathrm{~min}$.

\section{RESULTS}

\section{Quantity, quality and integrity of gDNA}

The total gDNA that was extracted from the unpreserved samples and samples that were fixed with Lugol's iodine and formaldehyde was mostly greater than $12 \mathrm{~kb}$ in length (Fig. 3). Some fragmentation was detected in the control and Lugol's samples with visible fragments of 1000 and $650 \mathrm{bp}$ (lanes 1 and 2, Fig. 3). In the glutaraldehyde-preserved samples, there was no visible DNA or signs of DNA degradation (lane

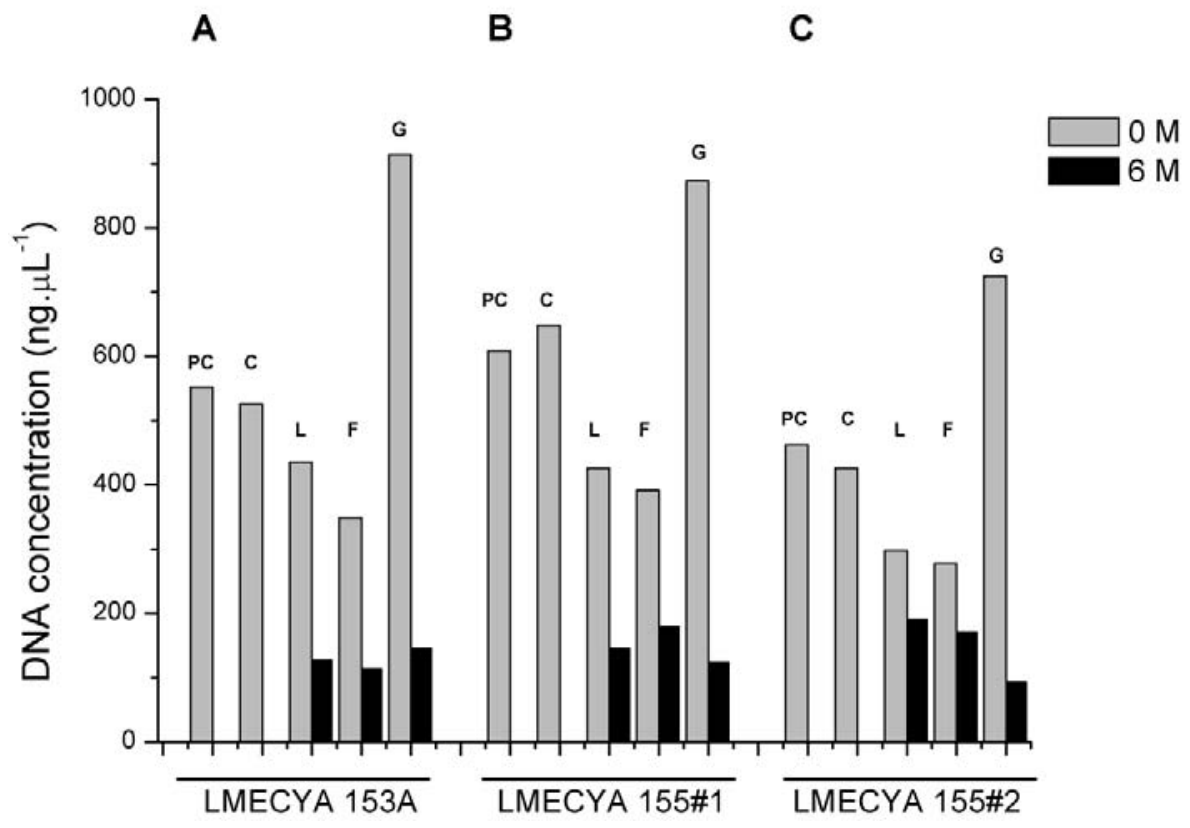

Figure 4. Total genomic DNA that was extracted from short-term- ( 0 months-0 $\mathrm{M}$ grey bars) and long-term- (6 months- $6 \mathrm{M}$ black bars) preserved culture samples in three independent experiments - (A) Planktothrix agardhii strain LMECYA 153A, (B and C) P. agardhii strain LMECYA 155. PC-positive control (no treatment), C-control (filter with no treatment), L-15\% Lugol's iodine solution, F-4\% formaldehyde, G-25\% glutaraldehyde. Cantidad total de DNA genómico extraído de muestras de cultivos conservadas poco tiempo (0 meses-0 M barra gris) y en períodos largos (6 meses-6 M barra negra) en tres experimentos independientes - (A) Planktothrix agardhii cepa LMECYA 153A, ( B y C) P. agardhii cepa LMECYA 155. PC-control positivo (sin tratamiento), C-control (filtro sin tratamiento), L-solución yodoyodurada de Lugol al 15\%, F-formaldehído al 4\%, G-glutaraldehído al $25 \%$. 
4, Fig. 3). Furthermore, a loss in DNA quantity was also visible in the preserved samples compared to that of the control samples (Fig. 3).

At the time of preservation, the DNA quantity was determined spectrophotometrically and decreased in the preserved samples compared to that of the control (Fig. 4). The samples that were preserved in Lugol's iodine showed a DNA loss of between 21 and $35 \%$ more than that of the control. For the formaldehyde-preserved samples, the loss was between 35 and $40 \%$. In contrast, for the glutaraldehyde-preserved samples, the DNA quantity was much higher than that of the control. This result is most likely unrealistic and misleading, given that no DNA was visible in the total-gDNA electrophoresis. Similar results were obtained in the 3 independent experiments (Fig. 4A, B and C). After 6 months of preservation, the quantity of DNA that was obtained from the preserved samples was substantially low compared to that of both the control and the same preserved samples at the time of preservation (Fig. 4). DNA losses ranged between $58 \%$ and $77 \%$ for Lugol'siodine-preserved samples and from $63 \%$ to $79 \%$ for formaldehyde-preserved samples.

The ratios OD260/OD280 and OD260/OD230 indicated good DNA quality from the control and positive control samples (Table 2). The DNA that was extracted from Lugol's- and formaldehydepreserved samples exhibited greater variability in quality ratios (Table 2). DNA isolated from glutaraldehyde samples showed poor DNA quality (Table 2). The quality of the DNA that was extracted from the short-term-preserved samples was similar to that from the six-month-preserved samples (Table 2).

\section{Real-time qPCR amplification of the preserved samples}

The DNA that was extracted from the recently preserved samples with the three tested fixatives was successfully amplified by real-time PCR in three independent experiments (Fig. 5A, B and C). For the Lugol's- and formaldehyde-preserved samples, the replicates were consistent, indicating correct target fragment detection in each of the 3 experiments (Fig. 5). Furthermore, a melting curve analysis of the amplified fragments in the Lugol's- and formaldehyde-preserved samples exhibited single melting peaks with high fluorescence, similar to that of the control. The replicate consistency and fragment amplification before PCR cycle 30 for the Lugol's- and formaldehyde-preserved samples caused the $\mathrm{Ct}$ values to fall in the standard curve quantification limits and enabled gene copy number quantification for these samples. However, this quantification was not realistic because the $\mathrm{Ct}$ values of the preserved samples were significantly higher than those of the control, which resulted in an underestimation of gene copy number (Fig. 5). In the glutaraldehyde-preserved samples, although the replicates were consistent, the $\mathrm{Ct}$ values were always measured after PCR cycle 30, except for in one experiment (Fig. 5A). The melting curve analysis for this last sample presented low fluorescence peaks at the melting temperature of the target fragment

Table 2. Genomic DNA quality. The values are present in the range of the OD260/OD280 and OD260/OD230 values that were obtained in the three experiments. The reference ratio values for good-quality DNA are OD260/280 $=1.8$ and OD260/230 $=2.0$. Calidad del DNA genómico extraído. Los valores estan apresentados en la gama de OD260/OD280 y OD260/OD230 obtenida en los tres experimentos realizados. Los valores de refencia indicativos de DNA de buena calidad son 1.8 para la razón OD260/OD280 y 2.0 para la razon OD260/OD230.

\begin{tabular}{lcccc}
\hline Preservation time & \multicolumn{3}{c}{ 0 months } & \multicolumn{2}{c}{ months } \\
\hline Quality ratios & OD260/OD280 & OD260/OD230 & OD260/OD280 & OD260/OD230 \\
Positive control & $1.84-1.91$ & $2.1-2.4$ & $1.85-1.93$ & $2.12-2.2$ \\
Control & $1.84-2.02$ & $1.9-2.36$ & $1.80-2.01$ & $1.97-2.09$ \\
Lugol's iodine & $1.70-1.87$ & $1.79-2.17$ & $1.81-1.98$ & $2.05-2.16$ \\
Formaldehyde & $1.44-1.92$ & $2.07-2.15$ & $1.63-1.78$ & $2.06-2.17$ \\
Glutaraldehyde & $1.39-1.59$ & $1.45-2.17$ & & $2.31-2.91$ \\
\hline
\end{tabular}


A

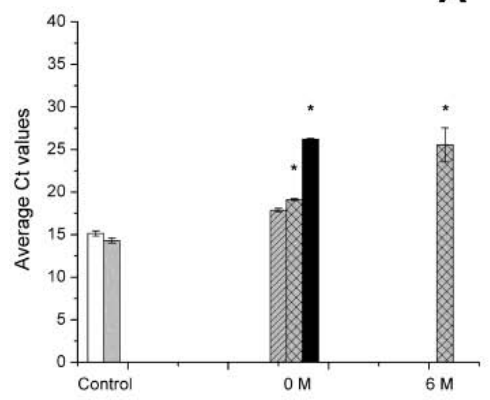

B

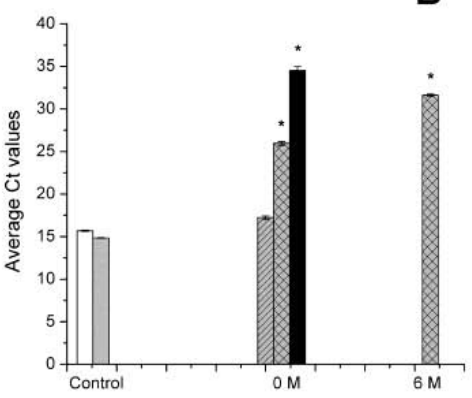

C

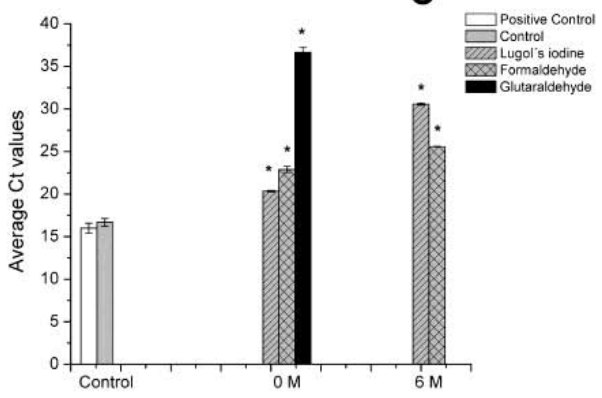

Figure 5. Comparison between the average $\mathrm{Ct}$ values that were obtained from the real-time amplification of non-preserved and preserved samples with 15\% Lugol's iodine solution, $4 \%$ formaldehyde and $25 \%$ glutaraldehyde in recently and six-month-preserved samples in three independent experiments - (A) Planktothrix agardhii strain LMECYA 153A (189 692 cells/reaction) and (B and C) $P$. agardhii strain LMECYA 155 (92 698 and 60828 cells/reaction, respectively). The asterisk denotes significant differences, Student's $t$ test, $\mathrm{df}=4, p<0.05$, between the Ct values of the preserved samples and the Ct values of the control at the time of preservation. The lines represent the standard deviation. Comparación entre los valores medios de Ct obtenidos de la amplificación por la PCR en tiempo real de muestras sin conservantes y muestras conservadas con solución yodoyodurada de Lugol al 15\%, formaldehído al $4 \%$ y glutaraldehído al $25 \%$ en muestras conservadas a corto y a largo plazo en tres experimentos independientes - (A) Planktothrix agardhii cepa LMECYA 153A (189692 células/reacción), (B y C) P. agardhii cepa LMECYA 155 (92 698 and 60828 células/reacción, respectivamente). El asterisco indica diferencias significativas, en la prueba $\mathrm{t}$ de Student, $d f=4, \mathrm{p}<0.05$, entre los valores de Ct de muestras conservadas y los valores de Ct del control en el momento de la preservación. Las líneas representan la desviación estándar.

when compared to that of the control. From the 3 fixatives that were used, the Lugol's-preserved samples presented a lower $\mathrm{Ct}$ value, followed by the formaldehyde- and glutaraldehyde-preserved samples (Fig. 5).
After six months of preservation, no reliable $\mathrm{Ct}$ values were obtained, except for in the formaldehyde-preserved samples in every experiment (Fig. 5A, B and C) and in the Lugol's-preserved samples in one experiment (Fig. 5C).

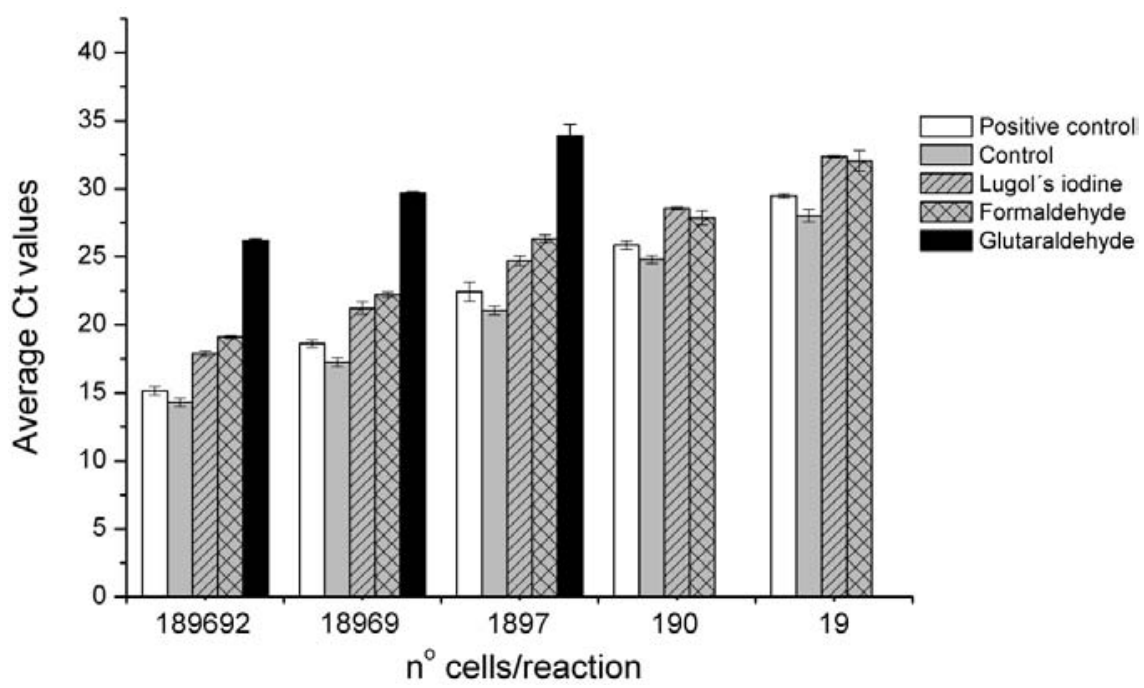

Figure 6. Sensitivity of the real-time PCR to target the rpoC1 gene in DNA that was extracted from P. agardhii strain LMECYA 153A when preserved in 15\% Lugol's iodine solution, $4 \%$ formaldehyde and $25 \%$ glutaraldehyde. The plotted bars represent the average $\mathrm{Ct}$ values of 5 serial 10-Logarithmic dilutions for each fixative solution. The lines represent the standard deviation. Sensibilidad de la PCR en tiempo real para amplificar el gen rpoC1 en DNA extraído a partir de P. agardhii cepa LMECYA 153A conservado con solución yodoyodurada de Lugol al 15\%, formaldehído al $4 \%$ y glutaraldehído al $25 \%$. Las barras representan los valores medios de Ct obtenidos de 5 series de 10 diluciones logarítmicas seriadas para cada solución de preservación. Las líneas representan la desviación estándar. 


\section{Real-time PCR inhibition and sensitivity}

To test for the presence of co-purified DNA PCR inhibitors, the real-time PCR amplification parameters were analysed in the 5 serial 10-fold dilutions of the preserved samples. In the amplification curves, the replicates of each 10 -fold dilution of the preserved sample with Lugol's and formaldehyde solutions were consistent, indicating amplification reproducibility. Furthermore, linearity was obtained for the Lugol's- and formaldehyde-preserved sample dilution series. For Lugol's-preserved samples, the regression equation was $y=-3.596 \log (x)+36.47$, with $r^{2}=0.997$ and a reaction efficiency of 0.90 . For the formaldehyde-preserved samples, the regression equation was $y=-3.197 \log (x)+35.69$, with $r^{2}=0.977$ and a reaction efficiency of 1.05 . No regression analysis could be drawn from the $\log$ dilutions of the glutaraldehyde samples.

The $\mathrm{Ct}$ values of the five serial 10-fold dilutions for each preserved sample and the con- trol are presented in figure 6. The amplification fluorescence at all of the concentrations ranged from 189692 to 190 cells per reaction in the samples that were preserved with Lugol's and formaldehyde solutions (Fig. 6). In the samples that were preserved with glutaraldehyde solution, the amplification products were only detected in the range of 189692 to 1897 cells per reaction (Fig. 6). Compared to conventional PCR, realtime PCR was able to amplify the target fragment at a lower concentration because the amplification products in conventional PCR were only obtained in the range of 189692 to 190 cells per reaction for the formaldehyde-preserved samples and 189692 cells per reaction for the glutaraldehyde-preserved samples (Fig. 7C and D).

\section{Applicability in the environmentally preserved samples}

To analyse the real-time PCR amplification of the target fragment in the preserved samples with

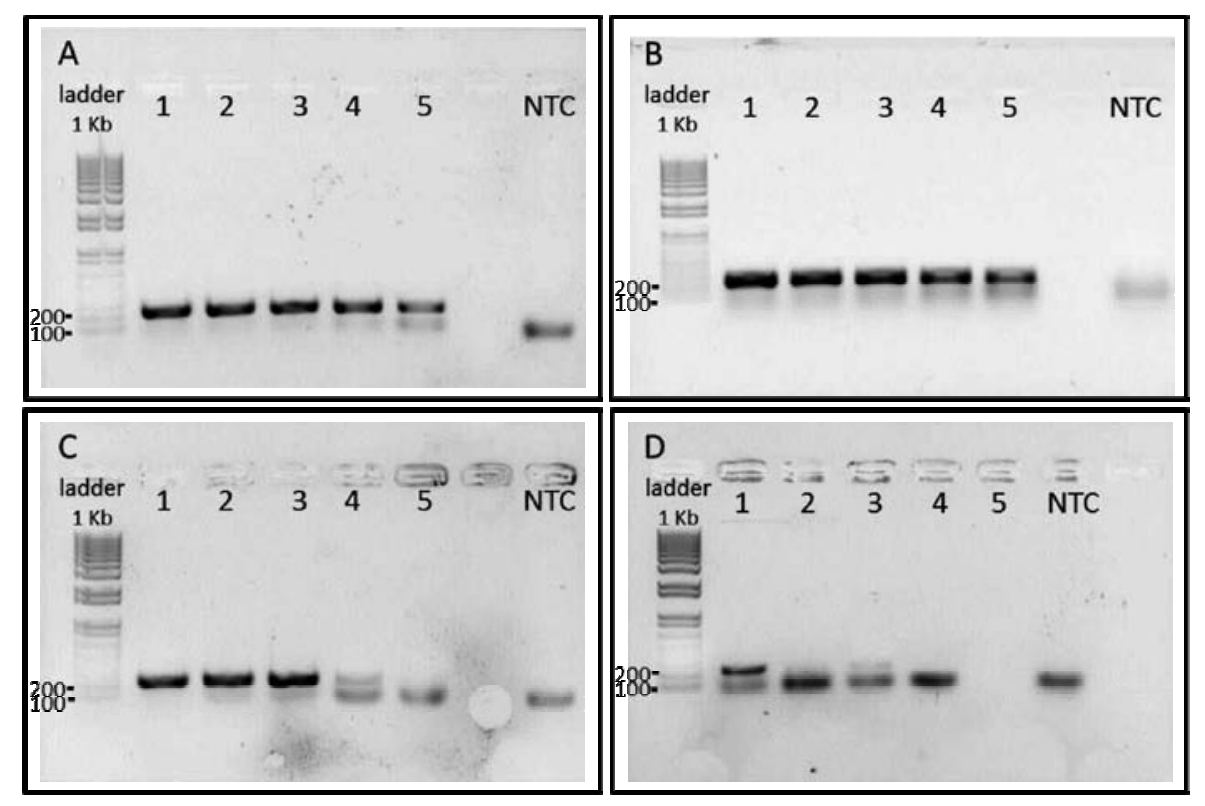

Figure 7. Gel image of conventional PCR showing the amplification of the rpoC1 gene target sequence of the $P$. agardhii strain LMECYA 153A DNA that was extracted from (A) control samples and samples that were preserved with (B) $15 \%$ Lugol's iodine solution, (C) $4 \%$ formaldehyde and (D) $25 \%$ glutaraldehyde. Lanes 1 to 5 refer to the 5 serial 10-fold dilutions of template DNA equivalent to 379384 to 38 cells/reaction. Ladder: GeneRuler ${ }^{\mathrm{TM}}$ DNA Ladder Mix (Fermentas); NTC: no-template control. Imagen Gel de la PCR convencional que muestra la amplificación del producto de DNA del gen rpoCl de la cepa P. agardhii LMECYA 153 A sin conservantes. (A) Control, y conservado con (B) solución yodoyodurada de Lugol al 15\% (C) formaldehído al $4 \%$ y (D) glutaraldehído al 25\%. Los carriles 1 a 5 se refieren a 5 series de 10 diluciones logarítmicas seriadas equivalentes a 379384 a 38 células/reacción. "Ladder”: marcador de peso molecular GeneRuler ${ }^{T M}$ Mix Ladder (Fermentas); NTC: control sin molde. 
an environmental matrix and cell concentrations, field samples were fixed with Lugol's solution, formaldehyde and glutaraldehyde. The $\mathrm{Ct}$ values for the preserved field samples are presented in figure 8. Positive amplification was obtained in the Lugol's- and formaldehyde-preserved field samples, and the rpoC1 fragment was successfully detected. Nevertheless, there was a significant difference between the $\mathrm{Ct}$ values of the preserved samples and that of the non-treated samples (Fig. 8). The resulting quantification of the target gene copy number in the preserved field sample resulted in an underestimation of the copy number compared to that of the control. Unlike culture experiments, a positive amplification was detected in the Lugol's-preserved sample after 6 months, and no amplification was obtained from the formaldehyde-preserved sample (Fig. 8).

\section{DISCUSSION}

The intent of sample preservation is to maintain cell integrity and morphology, and the most common fixatives that are used clearly fulfil this function. These preservatives began to be used a long time ago when nucleic acid availability was not yet a concern. In fact, fixatives such as formaldehyde and glutaraldehyde cross-link and coagulate proteins to maintain cellular and organellar structures, consequently trapping the DNA in the cell and making the DNA unavailable for PCR amplification (Douglas \& Rogers, 1998; Kiernan, 2000; Srinivasan et al., 2002). In addition, another reason for the lack of DNA availability from preserved samples includes cell loss during the preservation process. Several studies using formaldehyde-ciliate-fixed samples have reported more than $70 \%$ cell loss compared to that in Lugol's-preserved samples (Stoecker et al., 1994; Pitta et al., 2001; Modigh \& Castaldo, 2005). Furthermore, the fixative inclusion in the cells requires some time, and during the fixation process, the DNases that are present in the cells may destroy DNA (Noguchi et al., 1997; Srinivasan et al., 2002).

The results presented here demonstrate that cyanobacterial DNA can be amplified by real- time PCR using Lugol's- and formaldehydepreserved culture samples and in samples with a complex matrix, such as environmental samples. High molecular weight gDNA was obtained from Lugol's- and formaldehyde-preserved samples, and the observed fragmentation was also present in the DNA from the non-preserved sample, indicating that this fragmentation was not caused by the preservation treatment. However, the difference in the intensity of gDNA bands from these samples compared to that of the control suggests that the DNA losses were higher in the formaldehyde-preserved samples. In fact, the DNA concentrations measurements from the Lugol's- and formaldehyde-preserved samples also indicated severe DNA losses that increased with the time of preservation. The quality of the DNA that was extracted from the preserved samples was also inferior to that of the sample without treatment, suggesting that fixation decreases the DNA quality. Despite these drawbacks, the target fragment was successfully amplified in samples that were preserved in Lugol's and formaldehyde solutions for a short time and for six months, thus making real-time PCR analysis suitable for fragment detection in preserved samples. However, due to the increased $\mathrm{Ct}$ values, the quantification resulted in an underestimation of the gene copy number, meaning that, although the sample can be quantified, the results of that quantification are not realistic and cannot be related to the concentrations prior to fixation. Nevertheless, the target fragment amplification after six months of preservation presented variability in the results between experiments, which may be related to the fixative stability and sample degradation over time. To understand whether the shift in $\mathrm{Ct}$ values was also due to the inhibition of the PCR reaction and not only to DNA loss, the Lugol's- and formaldehyde-preserved samples were diluted, and the serial logarithmic dilutions amplified linearly with efficiencies close to 1 , indicating that no PCR inhibitors were present in the reaction. In the literature, the amplification of DNA that is extracted from Lugol's-preserved phytoplankton samples has been performed mainly with eukaryotic dinoflagellates, and 


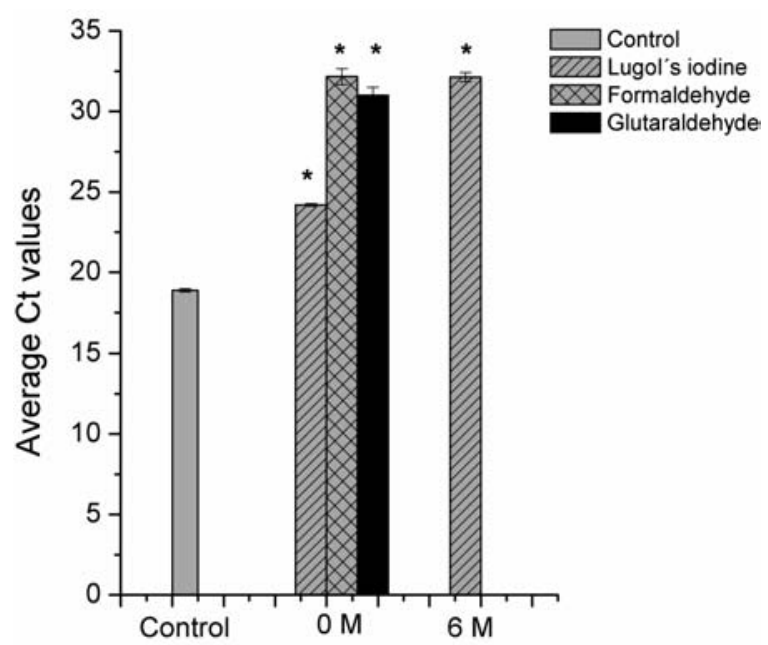

Figure 8. Comparison of the average $\mathrm{Ct}$ values that were obtained from the real-time amplification of environmental samples that were not preserved or preserved with $15 \%$ Lugol's iodine solution, $4 \%$ formaldehyde and $25 \%$ glutaraldehyde in recently $(0 \mathrm{M})$ and six-month- $(6 \mathrm{M})$ preserved samples. The asterisk denotes significant differences, Student's $t$ test, $\mathrm{df}=4$, $p<0.05$, between the $\mathrm{Ct}$ values of the preserved samples and the $\mathrm{Ct}$ values of the control at the time of preservation. The lines represent the standard deviation. Comparación entre los valores medios de Ct obtenidos de la amplificación por la PCR en tiempo real de muestras de campo sin conservantes y muestras conservadas con solución yodoyodurada de Lugol al $15 \%$, formaldehído al $4 \%$ y glutaraldehído al $25 \%$ en muestras de culturas conservadas a pronto y a largo. El asterisco indica diferencias significativas, en la prueba $\mathrm{t}$ de Student, $d f=4$, $\mathrm{p}<0.05$, entre los valores de Ct de muestras conservadas y los valores de Ct del control en el momento de la preservación. Las líneas representan la desviación estándar.

no information could be obtained regarding DNA amplification from preserved cyanobacteria samples. In experiments using dinoflagellates and microalgae DNA from Lugol's-preserved samples, Godhe et al. (2002) and Marín et al. (2001) were unable to obtain amplification with conventional PCR. In fact, positive results with conventional PCR have only been obtained with single-cell PCR experiments (Bertozzini et al., 2005; Auinger et al., 2008; Godhe et al., 2008; Henrichs et al., 2008; Kavanagh et al., 2010). However, when the real-time PCR technique was applied, successful amplification was reported for the amplification of dinoflagellate DNA (Bowers et al., 2000; Tengs et al., 2001; Galluzzi et al., 2004; Penna et al., 2007; Miyaguchi et al., 2008). Penna et al. (2007) and Galluzzi et al. (2004) reported that Lugol's solution did not induce
DNA loss in preserved samples with up to 15 months of preservation and that preserved samples were suitable for real-time PCR. However, similar to our results, previous reports in dinoflagellates have reported increased $\mathrm{Ct}$ values in Lugol's-preserved samples, reflecting a loss in the log cell concentration of 10-fold compared to that of unpreserved DNA; this decrease was also time dependent (Bowers et al., 2000; Miyaguchi et al., 2008). The reports regarding formaldehyde fixation in human tissue have also described the poor preservation of high-molecular-weight DNA and have reported that up to $30 \%$ of nucleic acids could be lost during fixation (Srinivasan et al., 2002). An identical result was also reported by Bertozzini et al. (2005), in which DNA recovery from formaldehyde-preserved phytoplankton samples was lower compared to that of un-preserved and Lugol's-preserved samples. Similar to our results, Miyaguchi et al. (2008) and Hosoi-Tanabe \& Sako (2005) also reported the successful target amplification of formaldehyde-preserved samples in real-time PCR and that fragment detection was inferior in formaldehyde-preserved samples compared to that in Lugol's-preserved and unpreserved samples. Based on our results, no conclusions can be drawn from the amplification of DNA from glutaraldehyde-preserved samples. No visible DNA was present in the total-gDNA gel migration, and the DNA quantification values were unrealistic and of poor quality. Most likely, glutaraldehyde was carried over during DNA extraction and interfered with the quality ratios, resulting in low OD260/OD280 and OD260/OD230 values, as glutaraldehyde has one absorbance peak at 235 and another at 280 nm (Jones, 1974; Gillett \& Gull, 1972; Hopwood et al., 1975). Consequently, the obtained $\mathrm{Ct}$ values were high, reflecting low-concentration DNA, and the observed amplification can be misleading because the signal is too close to residual fluorescence. In addition, no regression analysis could be drawn from the log dilutions of the glutaraldehyde samples. These results suggest that most of the DNA was lost during the preservation process, indicating that a much higher concentration of starting material is 
necessary for successful amplification, making the cell concentration in the context of preserved cyanobacteria samples unrealistic. Information about the use of DNA that is extracted from phytoplankton when preserved in glutaraldehyde is scarce. Using conventional PCR, Marín et al. (2001) were unable to obtain a positive PCR result with DNA from glutaraldehyde-preserved samples, while using real-time PCR, HosoiTanabe \& Sako (2005) were able to amplify DNA from glutaraldehyde-preserved samples and reported that the detection level was lower than that of untreated samples. In contrast to our results, studies of preserved samples of plant and fungi obtained high-molecular-weight DNA from glutaraldehyde-preserved samples and DNA yields that were similar to those of non-preserved samples, with positive PCR amplification (Douglas \& Rogers 1998).

\section{CONCLUSIONS}

In summary, Lugol's-iodine- and formaldehydepreserved cyanobacterial samples can be analysed using real-time PCR without these fixatives interfering with the reaction. The main factor jeopardizing the amplification of DNA from preserved samples seems to be the DNA loss during the fixation process, rather than fragmentation or PCR inhibition. This DNA loss occurs soon after fixation and increases over time, meaning that to overcome this issue, the preserved samples would have to be highly concentrated to minimize the effects of DNA loss. In this study, we used $25 \mathrm{~mL}$ of filtered field samples from a $P$. agardhii bloom and obtained a good fluorescence signal in real-time PCR. In field surveys, usually $100-$ to $1000-\mathrm{mL}$ samples are preserved for monitoring proposes. Such volumes should be more than adequate for proper real-time PCR detection. Furthermore, it is noteworthy that we have used a target gene that exists in single copy in the cyanobacteria genome; for genes presenting more than one copy in the cell, such as the 16S rRNA and microcystin synthetase genes, the availability of the target fragment could be higher.
This study shows that it is possible to use the real-time PCR technique in preserved cyanobacteria samples, thus providing access to molecular information that might be otherwise discriminated. Moreover, the high sensitivity of this technique, in contrast to that of conventional PCR, can be very useful for the fragment target detection of low-concentration samples that may result from the preservation process. However, the quantification that is achieved by the realtime PCR of the preserved samples cannot be related to or used to infer copy gene numbers of non-preserved samples. The use of this analysis to detect a specific species or a specific genotype in samples that arrive as fixed to the laboratory or that are preserved for some time can greatly increase the knowledge of bloom occurrence, specificity and toxicity and thus open a time capsule into water reservoir history.

\section{ACKNOWLEDGMENTS}

This research was supported by the Fundação para Ciência e Tecnologia, Portugal (FCT) through the project PPCDT/AMB/67075/2006. The authors also acknowledge the $\mathrm{PhD}$ research grant SFRH/BD65706/2009 to C. Churro and the Post-Doc research grant SFRH/BPD/75922/2011 to E. Valério.

\section{REFERENCES}

AUINGER, B. M., K. PFANDL \& J. BOENIGK. 2008. Improved methodology for identification of protists and microalgae from plankton samples preserved in Lugol's iodine solution: combining microscopic analysis with single-cell PCR. Applied and Environmental Microbiology, 74(8): 2505-2510.

BERTOZZINI, E., A. PENNA, E. PIERBONI, I. BRUCE \& M. MAGNANI. 2005. Development of new procedures for the isolation of phytoplankton DNA from fixed samples. Journal of Applied Phycology, 17(3): 223-229.

BOWERS, H. A., T. TENGS, H. B. GLASGOW, J. M. BURKHOLDER, P. A. RUBLEE \& D. W. OLDACH. 2000. Development of Real-Time 
PCR assays for rapid detection of Pfiesteria piscicida and related dinoflagellates. Applied and Environmental Microbiology, 66(11): 4641-4648.

CHURRO, C., P. PEREIRA, V. VASCONCELOS \& E. VALÉRIO. 2012. Species-specific real-time PCR cell number quantification of the bloomforming cyanobacterium Planktothrix agardhii. Archives of Microbiology, 194(9): 749-757.

DOUGLAS, M. P. \& S. O. ROGERS. 1998. DNA damage caused by common cytological fixatives. Mutation Research, 401(1-2): 77-88.

EDLER, L., \& M. ELBRÄCHTER. 2010. The Utermöhl method for quantitative phytoplankton analysis. In: Microscopic and molecular methods for quantitative phytoplankton analysis. KARLSON, B., CUSACK, C. \& E. BRESNAN (ed.). Intergovernmental Oceanographic Commission of UNESCO 2010. Paris, UNESCO. Chapter 2: 13-20.

GALLUZZI, L., A. PENNA, E. BERTOZZINI, M. VILA, E. GARCÉS \& M. MAGNANI. 2004. Development of a real-time PCR assay for rapid detection and quantification of Alexandrium minutum (a Dinoflagellate). Applied and Environmental Microbiology, 70(2): 1199-1206.

GILLETT, R. \& K. GULL. 1972. Glutaraldehyde - Its purity and stability. Histochemie, 30: 162-167.

GODHE, A., D. M. ANDERSON \& A.-S. REHNSTAM-HOLM. 2002. PCR amplification of microalgal DNA for sequencing and species identification: studies on fixatives and algal growth stages. Harmful Algae, 1: 375-382.

GODHE, A., M. E. ASPLUND, K. HÄRNSTRÖM, V. SARAVANAN, A. TYAGI \& I. KARUNASAGAR. 2008. Quantification of diatom and dinoflagellate biomasses in coastal marine seawater samples by Real-Time PCR. Applied and Environmental Microbiology, 74 (23): 7174-7182.

HENRICHS, D., M. RENSHAW, C. SANTAMARIA, B. RICHARDSON, J. GOLD \& L. CAMPBELL. 2008. PCR amplification of microsatellites from single cells of Karenia brevis preserved in $\mathrm{Lu}-$ gol's iodine solution. Marine biotechnology, 10(2): 122-127.

HOPWOOD, D. 1975. The reactions of glutaraldehyde with nucleic acids. Histochemical Journal, 7: 267-276.

HÖTZEL, G. \& R. CROOME. 1999. A phytoplankton methods manual for Australian freshwaters. Land and Water Resources Research and Development Corporation. Canberra.
HOSOI-TANABE, S. \& Y. SAKO. 2005. Speciesspecific detection and quantification of toxic marine dinoflagellates Alexandrium tamarense and A. catenella by real-time PCR assay. Marine Biotechnology, 7: 506-514.

JONES, G. S, 1974. Polymerization of glutaraldehyde at fixative $\mathrm{pH}$. Journal of Histochemistry \& Cytochemistry, 22: 911-913.

KARLSON, B., CUSACK, C. \& E. BRESNAN. 2010. Microscopic and molecular methods for quantitative phytoplankton analysis. Intergovernmental Oceanographic Commission of UNESCO. Paris, UNESCO.

KAVANAGH, S., C. BRENNAN, L. O'CONNOR, S. MORAN, R. SALAS, J. LYONS, J. SILKE \& M. MAHER. 2010. Real-time PCR detection of Dinophysis species in Irish coastal waters. Marine Biotechnology, 12(5): 534-542.

KIERNAN, J. 2000. Formaldehyde, formalin, paraformaldehyde and glutaraldehyde: What they are and what they do. Microscopy Today, 00-1: 8-12.

LANG, I. \& I. KACZMARSKA. 2011. A protocol for a single-cell PCR of diatoms from fixed samples: method validation using Ditylum brightwellii (T. West) Grunow. Diatom Research, 26(1): 43-49.

MARÍN, I., A. AGUILERA, B. REGUERA \& J. P. ABAD. 2001. Preparation of DNA suitable for PCR amplification from fresh or fixed single dinoflagellate cells. BioTechniques, 30: 88-93.

MENDEN-DEUER, S., E. J. LESSARD \& J. SATTERBERG. 2001. Effect of preservation on dinoflagellate and diatom cell volume and consequences for carbon biomass predictions. Marine Ecology Progress Series, 222: 41-50.

MIYAGUCHI, H., N. KUROSAWA \& T. TODA. 2008. Real-time polymerase chain reaction assays for rapid detection and quantification of Noctiluca scintillans zoospore. Marine biotechnology, 10(2): 133-140.

MODIGH, M. \& S. CASTALDO. 2005. Effects of fixatives on ciliates as related to cell size. Journal of Plankton Research, 27(8): 845-849.

NOGUCHI, M., J. S. FURUYA, T. TAKEUCHI, \& S. HIROHASHI. 1997. Modified formalin and methanol fixation methods for molecular biological and morphological analyses. Pathology International, 47(10): 685-691.

PAULINO, S., F. SAM-BENTO, C. CHURRO, E. ALVERCA, E. DIAS, E. VALÉRIO \& P. PEREIRA. 2009. The Estela Sousa e Silva Algal Culture Collection: a resource of biological and 
toxicological interest. Hydrobiologia, 636(1): 489-492.

PENNA, A., E. BERTOZZINI, C. BATTOCCHI, L. GALLUZZI, M. G. GIACOBBE, M. VILA, E. GARCES, A. LUGLIÈ \& M. MAGNANI. 2007. Monitoring of HAB species in the Mediterranean Sea through molecular methods. Journal of Plankton Research, 29(1): 19-38.

PITTA, P., A. GIANNAKOUROU \& U. CHRISTAKI. 2001. Planktonic ciliates in the oligotrophic Mediterranean Sea: longitudinal trends of standing stocks, distributions and analysis of food vacuole contents. Aquatic Microbial Ecology, 24(3): 297-311.

QIU, D., L. HUANG, S. LIU \& S. LIN. 2011. Nuclear, mitochondrial and plastid gene phylogenies of Dinophysis miles (Dinophyceae): evidence of variable types of chloroplasts. Plos one, 6(12): 112.

SHUANG, X., Y. CHENG, H. ZHU, G. LIU \& Z. HU. 2013. Improved methodology for identification of Cryptomonads: combining light microscopy and PCR amplification. Journal of Microbiology and Biotechnology, 23(3): 289-296.

SRINIVASAN, M., D. SEDMAK \& S. JEWELL. 2002. Effect of fixatives and tissue processing on the content and integrity of nucleic acids. The American Journal of Pathology, 161(6):
1961-1971.

STOECKER, D. K., D. J. GIFFORD \& M. PUTT. 1994. Preservation of marine planktonic ciliates: losses and cell shrinkage during fixation. Marine Ecology Progress Series, 10: 293-299.

TENGS, T., H. A. BOWERS, A. P. ZIMAN, D. K. STOECKER, \& D. W. OLDACH. 2001. Genetic polymorphism in Gymnodinium galatheanum chloroplast DNA sequences and development of a molecular detection assay. Molecular Ecology, 10(2): 515-523.

UTKILEN, H., J. FASTNER \& J. BARTRAM. 1999. Fieldwork: site inspection and sampling. In Toxic Cyanobacteria in Water: A guide to their public health consequences, monitoring and management, I. Chorus \& J. Bartram (ed.): 334-361. WHO, London, UK.

VINOD, K. K. 2004. Total genomic DNA extraction, purity analysis and quantitation. Presented in the CAS training program on "Exploiting Hybrid Vigour in Crop Plants Through Breeding and Biotechnological Approaches". Centre for Plant Breeding and Genetics, 92-104, Tamil Nadu Agricultural University. Coimbatore, India.

WILSON, I. G. 1997. Inhibition and facilitation of nucleic acid amplification. Applied and Environmental Microbiology, 63(10): 3741-3751. 